Arq. Bras. Med. Vet. Zootec., v.56, n.3, p.408-410, 2004

\title{
Communication
}

[Comunicação]

\section{Determination of the minimal representative number of microscopic fields to quantify apoptosis in canine lymph nodes}

[Determinação do número mínimo representativo de campos microscópicos para quantificar apoptose em linfonodos caninos]

\author{
L. Moro ${ }^{1}$, A.C. Vasconcelos $^{1}$, F.G.A. Santos ${ }^{2}$, C.M. Alves ${ }^{3}$, J.E.S. Nunes ${ }^{4}$, I.B.M. Sampaio ${ }^{5}$ \\ ${ }^{1}$ Instituto de Ciências Biológicas - UFMG \\ Avenida Antônio Carlos, 6627 \\ 31270-901 - Belo Horizonte, MG \\ ${ }^{2}$ Doutorando em Ciência Animal - ICB-UFMG \\ ${ }^{3}$ Bolsista de iniciação científica \\ ${ }^{4}$ Mestrando em Patologia Geral - ICB-UFMG \\ ${ }^{5}$ Escola de Veterinária - UFMG
}

Apoptosis seems to contribute to lymphoid depletion. However quantifying this type of cell death in lymphoid tissues is not an easy task. The apoptotic indices in lymph nodes vary considerably from field to field and from specimen to specimen. Statistical methods to reach representative sampling in such situation include measuring three to 10 microscopic fields, randomly. The sampling is considered acceptable if the coefficient of variation is between 20 to $30 \%$, which is reasonable for most of the biological variables (Sampaio, 1998).

An alternative sampling method was proposed by Williams (1977). That method is based upon the calculation of the accumulated means of the event that is intended to be evaluated. Then data are plotted in a graph and the acceptable variation level is established.

The aim of this study was to calculate the minimal representative number of microscopic fields in the same animal to constitute each sample repetition.

The tracheobronchial lymph node of a dog with distemper disease was collected and processed routinely for histological examination. Sections of $5 \mu \mathrm{m}$ were stained with Shorr (Merck, Darmstadt, Germany - cat \# 9275). Apoptotic indices (i.e. apoptotic cells/total cells) and number of apoptotic cells from 300 microscopic fields (at a higher magnification - 1000x) in the same slide were registered, using a digital image analyzer. Images were obtained by a microscopy connected to a camera, transferred to a digitalyzer plate and the morphometry was performed by a computer using a specific software (Kontron KS 300 V 2.0). The determination of the minimal representative number of microscopic fields to establish the cut off value to quantify apoptosis in canine lymph node was reached through the analysis of the instability of the standard deviation of the mean (Sampaio, 1998). Ten sample means of 5, 10, 15, $20,25,30,35,40,45$ and 50 random fields were set as experimental units and had their descriptive statistics calculated. Standard deviation of the mean (SD) for each sample was plotted against its size to visualize SD trend.

SD values decreased as the number of microscopic fields in the sample increased (Fig. 1 and 2). When the oscillations of the SD's between consecutive samples were smaller than $5 \%$, a reliable cut off was established, since the

Recebido para publicação em 28 de fevereiro de 2003 
number of fields in that sample was considered representative enough to dispense larger sampling. Such stabilization of SD's occurred at 40 fields per slide in this study (Fig. 1 and 2). Therefore the analysis of 40 fields per slide in a search for apoptotic indices in canine lymph nodes is representative enough, since this number presents acceptable instability. This statistical approach minimizes error mean square by setting a cut off value and consequently increases the design efficiency.

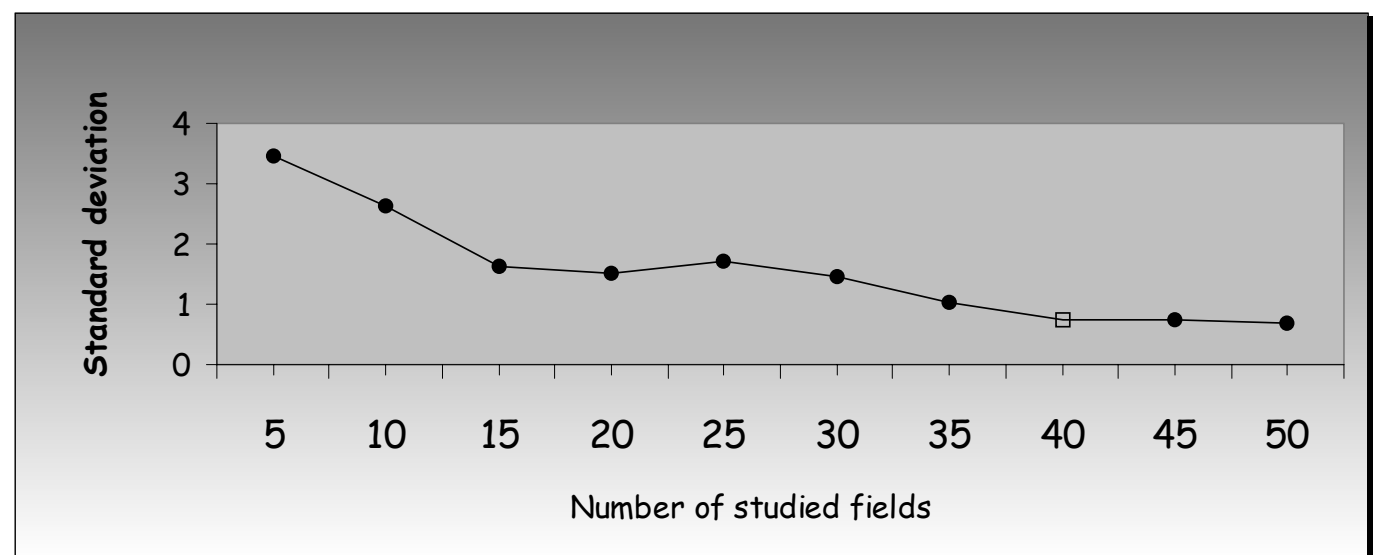

Figure 1. Standard deviation of sample means according to the specific number of microscopic fields, in the study of apoptotic cells. $\square$ Cut off.

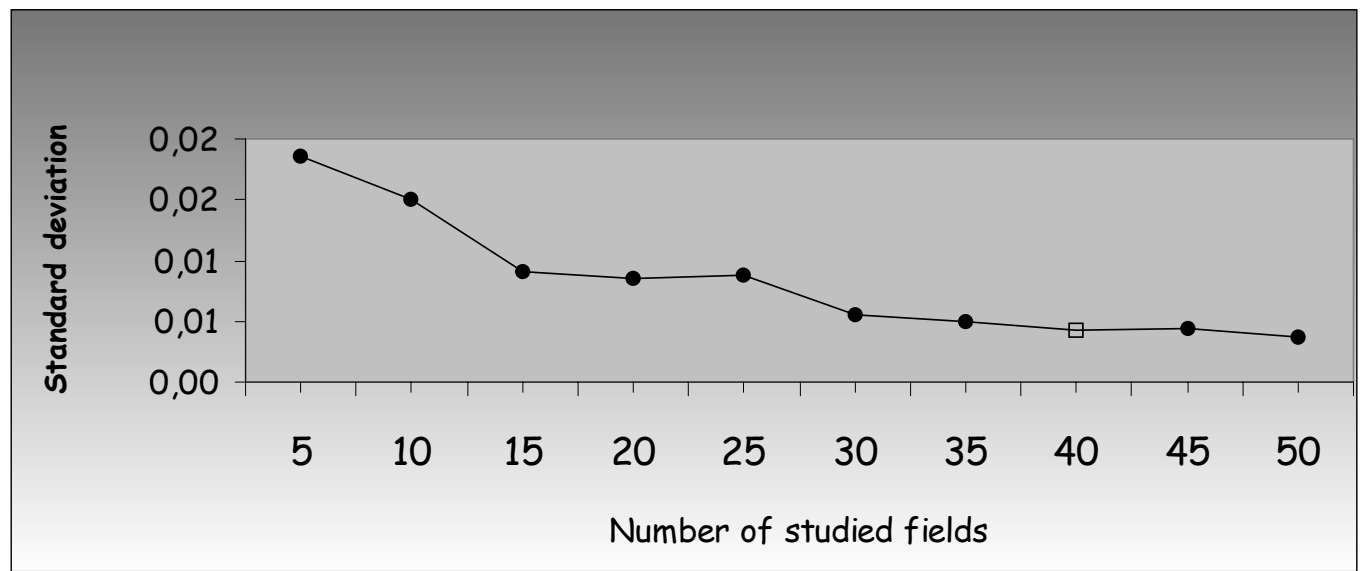

Figure 2. Standard deviation of sample means according to the specific number of microscopic fields, in the study of apoptotic index. $\square$ Cut off.

Quantifying cells is always time consuming and tiresome and this approach is enough to dispense the counting of larger samples.
Keywords: dog, apoptosis, morphometry, lymph node, sampling 


\section{RESUMO}

Determinou-se o número mínimo de campos por lâmina para se ter uma amostragem representativa para $o$ estudo de apoptose em linfonodos de cães com cinomose. Um linfonodo traqueobrônquico de cão foi colhido e processado segundo técnica para inclusão em parafina. Secções de 5 um foram coradas pelo tricrômico de Shorr. Utilizou-se um analisador de imagens para registrar o número de células em apoptose e os índices apoptóticos de 300 campos, na mesma lâmina. Obtiveram-se, então, valores médios para 10 amostras de 5, 10, 15, 20, 25, 30, 35, 40, 45 e 50 campos ao acaso. Realizou-se o estudo dos desvios-padrão das médias (DP) em relação ao tamanho da amostra que os originou. Quando as oscilações de DP entre amostras consecutivas foram menores que 5\%, o ganho em representatividade produzido pelo acréscimo no número de campos não se justificou, dispensando amostragens maiores. Desse modo, a análise de 40 campos por lâmina, na pesquisa de índices apoptóticos em linfonodos caninos, é suficientemente representativa, uma vez que apresenta instabilidade aceitável.

Palavras-chave: cão, apoptose, morfometria, linfonodo, amostragem

\section{ACKNOWLEDGEMENTS}

We thank Dr. Almir de Sousa Martins for his helpful suggestions; the CCZ (Centro de Controle de Zoonoses- Belo Horizonte, MG, Brasil) for its help; CAPES (Conselho de Aperfeiçoamento de Pessoal de Nível Superior Brasil) and $\mathrm{CNPq}$ (Conselho Nacional de Pesquisa - Brasil) for its grants. This paper was presented at the National Meeting of Veterinary Pathology, Belo Horizonte, Minas Gerais, Brasil, July 1999.

\section{REFERENCES}

SAMPAIO, I.B.M. Estatística aplicada à experimentação animal. Belo Horizonte: Fundação de Ensino e Pesquisa em Medicina Veterinária e Zootecnia, 1998. 221p.

WILLIAMS, M.A. Quantitative methods in biology. In: GLAUBERT, A.M. Practical methods in electron microscopy. Amsterdam: Elsevier, 1977. v.6, 233p. 